\title{
Community dynamics of intertidal soft-bottom mussel beds over two decades
}

\author{
Heike Büttger · Harald Asmus · Ragnhild Asmus • \\ Christian Buschbaum · Sabine Dittmann · \\ Georg Nehls
}

Received: 1 August 2007/Revised: 30 November 2007/Accepted: 4 December 2007/Published online: 10 January 2008

(C) Springer-Verlag and AWI 2007

\begin{abstract}
Macrozoobenthos communities in the North Sea showed pronounced changes over the past decade in relation to an increasing number of invasive species and climate change. We analysed data sets spanning 22 years on abundance, biomass and species composition of intertidal soft bottom mussel beds near the island of Sylt (German Bight) in the Northern Wadden Sea, based on surveys from 1983/ 1984, 1990, 1993 and from 1999 to 2005. Mussel bed area and blue mussel biomass decreased, and a change in the dominance structure in the associated community comparing 1984 to mid-1990s with the period from 1999 to 2005 was observed. Coverage of the mussel beds with the algae Fucus vesiculosus decreased since the end of the 1990s. Within the study period biomass and densities of the associated community increased significantly. Dominance structure changed mainly because of increasing abundances of associated epibenthic taxa. Apart from the Pacific oyster Crassostrea gigas all other alien species were already present in the area during the study period. Community changes already started before Pacific oysters became abundant. An attempt is made to evaluate effects on the observed changes of decreasing mussel biomass, ageing of mussel beds, decreasing fucoid coverage and increasing abundances of
\end{abstract}

Communicated by J. van Beusekom.

\footnotetext{
H. Büttger $(\bowtie) \cdot$ G. Nehls

BioConsult SH, Brinckmannstr. 31, 25813 Husum, Germany

e-mail: h.buettger@bioconsult-sh.de
}

H. Asmus · R. Asmus - C. Buschbaum

Alfred Wegener Institute for Polar and Marine Research,

Wadden Sea Station Sylt, 25992 List/Sylt, Germany

S. Dittmann

School of Biological Sciences, Flinders University,

GPO Box 2100, Adelaide, SA 5001, Australia invader. All four factors are assumed to contribute to changing community structure of intertidal mussel beds.

Keywords Mytilus edulis - Crassostrea gigas . Ecosystem engineers - Mussel bed community . Macrozoobenthos · Wadden Sea

\section{Introduction}

Worldwide, coastal systems have undergone dramatic changes in recent decades, in particular due to eutrophication, climate change and introduced species (Valiela 2005; Philippart et al. 2007). Eutrophication often increases primary production and climate variations may enhance or depress recruitment success (Hagberg et al. 2004; Philippart et al. 2007). Global warming is expected to accelerate the establishment of non-indigenous species in North Sea waters (Stachowicz et al. 2002; Diederich et al. 2005).

Surveys in the Wadden Sea and adjacent North Sea documented major changes of macrobenthic communities in the past decades (Reise 1982, Beukema 1991, 1992). Kröncke et al. (2001) described how climate oscillations influence the occurrence and density of subtidal macrozoobenthos in the southern North Sea, with significant increases in species number, abundance and biomass after mild winters. Franke and Gutow (2004) and Reichert and Buchholz (2006) documented changes of the inter- and subtidal hard-bottom macrozoobenthos community at Helgoland since 1984, recording losses of species as well as the immigration of southern species.

Invasive species contribute significantly to community changes in the Wadden Sea (Nehring and Leuchs 1999; Reise et al. 2005). The introduced Pacific oyster (Crassostrea gigas) and the American slipper limpet (Crepidula 
fornicata) have become abundant on blue mussel beds (Mytilus edulis) in the entire Wadden Sea (Thieltges et al. 2003; Diederich 2005; Smaal et al. 2005), particularly in the past 5 years. An increasing number of former mussel beds are now overgrown by oysters forming massive reefs (Diederich 2005, Nehls and Büttger 2007). At the same time, mussel bed area has decreased strongly, because of a lack of recruitment in some areas (de Vlas et al. 2005, Nehls et al. 2006).

Mussel beds are complex entities that provide refuge and suitable habitat for an array of associated organisms (e.g. Suchanek 1980; Tsuchiya and Nishihira 1985, 1986). Blue mussel beds on soft bottoms can be classified as autogenic ecosystem engineers, being a habitat distinctly different from the surrounding tidal flats (Jones et al. 1994; Buschbaum and Saier 2001; Crooks 2002; Gutiérrez et al. 2003). Soft bottom intertidal mussel beds in the Wadden Sea are centers of high diversity (Asmus 1987; Dittmann 1990; Albrecht and Reise 1994), providing substrate for attachment and refuge as well as habitat for many endobenthic species. Biomass and species richness are usually much higher than on surrounding tidal flats. The associated fauna, as well as the mussels themselves, form a rich food source for many predators, such as crabs, starfish and birds (e.g. Beukema 1991; Thiel and Dernedde 1994; Hertzler 1995).

Most field studies and experiments on community structure and dynamics of mussel beds have been short term. Yet, long-term variations and gradual changes in the environment, erratic spatfalls and strong effects of storms or ice cover during winter (Nehls and Thiel 1993; Reise et al. 1994; Strasser et al. 2001) also need to be considered.

In this paper, we present for the first time a long-term study analysing the community structure of intertidal mussel beds in the Wadden Sea, relying on a series of studies from 1983 to 2005 .

This data set allowed us to raise the following questions:

(1) Did the physical structure of the mussel bed change in terms of area or mussel density and biomass? (2) Did the associated community change in terms of composition and/ or abundances? and (3) Did the community respond to structural changes or introduced species?

\section{Methods}

Study site

All data analysed in this long-term comparison were obtained in Königshafen, a shallow tidal bay comprising about $4.5 \mathrm{~km}^{2}$ of intertidal flats near the island of Sylt in the northern Wadden Sea (south-eastern North Sea, German Bight; Fig. 1). The tides are semi-diurnal with an average range of about $2 \mathrm{~m}$. Salinity remains close to 30 psu and mean water temperature is $15^{\circ} \mathrm{C}$ in summer and
Fig. 1 Study area in the Wadden Sea near the island of Sylt (German Bight). Inset shows location of mussel beds, site 1 (Uthörn Außenwatt) and site 2 (Odde Watt), in 1989 (dark grey $=$ islands and mainland, light grey $=$ intertidal, white $=$ subtidal areas)

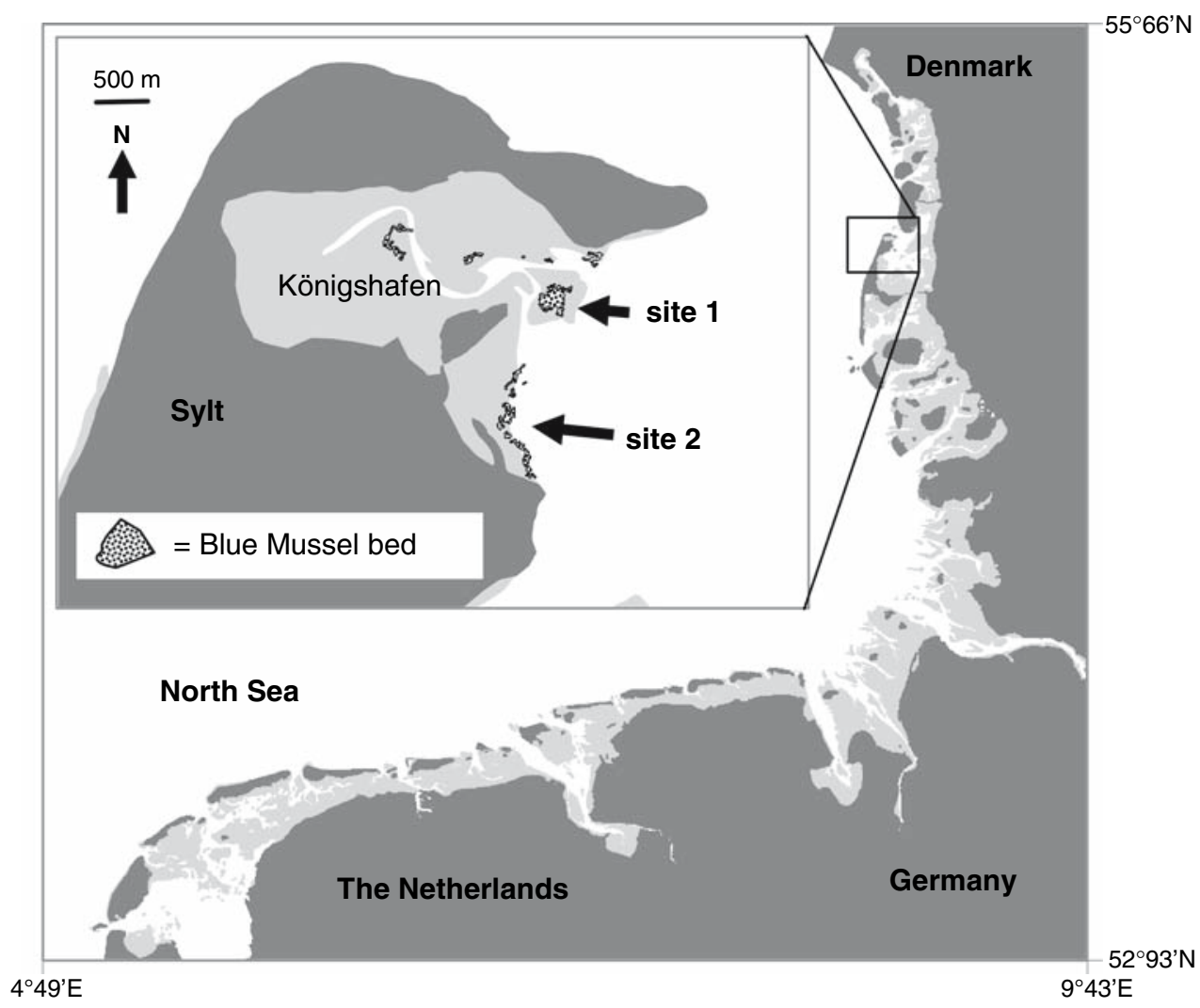


$4^{\circ} \mathrm{C}$ in winter. Detailed information on hydrography, geology, sediments and biota of the area are available from Reise (1985), Austen (1994a, b) and Gätje and Reise (1998). Mussel beds cover up to $5 \%$ of the intertidal area of the Königshafen, which is considerably higher than the average of about $1 \%$ of the Wadden Sea (de Vlas et al. 2005). Most mussel beds are situated in the outer parts of the Königshafen close to low water line.

\section{Database}

Data on mussels and species associated with soft-bottom mussel beds were available from two adjacent beds situated in the eastern part of Königshafen (Fig. 1), which generally were found to be similar in structure, density and biomass of mussels.

This paper is based on four separate studies (Table 1). Sampling was carried out between August and November in each year.

Details in sampling strategy differed between the four studies and mainly relate to the diameter and the depth of the corer and numbers of samples. Corers used by Albrecht (1991) and Hertzler (1995) only reached a sediment depth of $10-15 \mathrm{~cm}$, compared to $30 \mathrm{~cm}$ in the other studies; thus a few deeper burrowing endobenthic taxa may be somewhat underrepresented in their samples. However, only very few species occurring on mussel beds in the Wadden Sea burrow deeper than $15 \mathrm{~cm}$, and Albrecht and Reise (1994) did not find living macrofauna below $15 \mathrm{~cm}$. Thus, we regard these methodological differences as less important. Methods used in the first and the most recent study were almost identical, except for the mesh size (Table 1). Since 1999, macrozoobenthos of mussel beds in the study area have been included in a long-term monitoring of blue mussel beds in the Wadden Sea following the standardized methods of the Trilateral Monitoring and Assessment Program (Trilateral Monitoring and Assessment Group 1997). Sample treatment followed common standards in species determination and in measuring biomass as ash-free dry weight. We also used biomass data (Sept 1990, Oct, 1991, April 1992) and densities (Sept. 1990, Oct. 1991) from Nehls and Ketzenberg (2002). Data from 1997 are from Schürmann (1998). Data from both mussel bed sites were pooled.

The mussel beds are located close to the tidal inlet connecting the List tidal basin with the North Sea. Biomass and productivity used to be considerably higher than that in other parts of the Wadden Sea (Asmus 1987; Nehls and Ketzenberg 2002). The structure of the mussel beds analysed in this study was similar in the eighties and nineties, with a mussel cover of $25-30 \%$ containing high densities and biomass. Densities and length-frequency distributions were rather similar in the early nineties, when samples were taken on both mussel bed sites (Nehls and Ketzenberg 2002). The mussel bed on site 2 was destroyed by storms in 1998 and last sampled in September 1998, when samples were also taken on site 1 . Densities and biomass (live wet weight) in September 1998 were 2,570 ind. $/ \mathrm{m}^{2}$ and $12,786 \mathrm{~g} / \mathrm{m}^{2}$ on site 2 , and $2,079 \mathrm{ind} . / \mathrm{m}^{2}$ and $13,534 \mathrm{~g} / \mathrm{m}^{2}$ on site 1. Fucus coverage was estimated to be about $75 \%$ on both sites (G. Nehls, unpubl.). Tidal elevation and sediment characteristics were similar on both sites as well; thus no obvious differences between the sites occurred which could confound changes of associated fauna.

Not all organisms were determined to species level in every year. These inconsistencies required combination of some taxa to ensure consistency. These taxa are Actinaria indet., Balanus sp., Cirratulidae indet., Malacoceros sp.,

Table 1 Sources of database

\begin{tabular}{|c|c|c|c|c|c|c|c|}
\hline Data source & $\begin{array}{l}\text { Year of } \\
\text { investigation }\end{array}$ & $\begin{array}{l}\text { Mussel } \\
\text { bed }\end{array}$ & $\begin{array}{l}\text { Core } \\
\text { size } \\
\left(\mathrm{cm}^{2}\right)\end{array}$ & $\begin{array}{l}\text { Mesh } \\
\text { size } \\
\text { of the } \\
\text { sieve } \\
(\mathrm{mm})\end{array}$ & $\begin{array}{l}\text { Sample } \\
\text { depth } \\
(\mathrm{cm})\end{array}$ & Sampling method & Data basis \\
\hline $\begin{array}{l}\text { Asmus (1987 and } \\
\text { unpubl. data) }\end{array}$ & $1983 / 1984$ & Site 2 & 100 & 0.5 & 30 & $\begin{array}{l}\text { Six sites with five samples each } \\
\quad(n=30)\end{array}$ & $\begin{array}{l}\text { Mean densities for September } \\
\text { to November } 1984\end{array}$ \\
\hline Albrecht (1991) & 1990 & Site 2 & 500 & 0.5 & 15 & $\begin{array}{l}\text { Six samples within and six outside } \\
\text { fucus-covered parts of the } \\
\text { mussel bed }(n=12)\end{array}$ & $\begin{array}{l}\text { Mean densities, samples taken } \\
\text { in August } 1990\end{array}$ \\
\hline Hertzler (1995) & 1993 & Site 2 & 500 & 1 & $10-15$ & $\begin{array}{l}\text { Six samples at the edge of the } \\
\text { mussel beds, in parts covered } \\
\text { with fucus and parts without } \\
\text { fucus, respectively }(n=18)\end{array}$ & $\begin{array}{l}\text { Mean densities, samples taken } \\
\text { in August } 1993\end{array}$ \\
\hline $\begin{array}{l}\text { Mussel monitoring } \\
\text { (unpubl. data) }\end{array}$ & 1999-2005 & Site 1 & 113 & 1 & 30 & $\begin{array}{l}\text { Between } 1999 \text { and } 2002 n=10 \\
\quad \text { each year, since } 2003 n=25 \\
\quad \text { each year }\end{array}$ & $\begin{array}{l}\text { Mean densities, sampling in } \\
\text { September }\end{array}$ \\
\hline
\end{tabular}

See Fig. 1 for site location 
Nemertea indet., Nephtyidae indet., Neridae indet., Phyllodoce sp. and Tellinidae indet.. Data merely given as Spionidae indet., Polychaeta indet. and Phyllodocidae indet. were not included. We did not include Hydrozoa and Bryozoa. Furthermore, we did not incorporate Oligochaeta indet. because of insufficient sampling methods (mesh size) for this group in most years.

\section{Fucus cover}

The percentage of the mussel beds covered by Fucus vesiculosus forma mytili (hereafter, Fucus) was estimated visually in the surveys in 1984 and 1990, and additionally by Parusel (1990) in 1988. Since 1998, the cover has been determined in September each year. This special form of Fucus does not possess holdfasts, and mussels attach it with their byssus threads (Albrecht and Reise 1994).

\section{Statistical analyses}

Data are presented as mean values with standard deviation $(\bar{x} \pm \mathrm{SD})$. Effects of time and blue mussel densities on the density and biomass of the associated fauna were analysed with the rank correlation after Spearman $\left(r_{\mathrm{s}}\right)$. Results for effects of time on densities of single species with less than five data-pairs were not included. Effects were considered statistically significant if $P<0.05$.

For community analysis the PRIMER Program Package v6 was used (Clarke and Warwick 2001). To analyse changes in community composition between years we used a multi-dimensional scaling plot (MDS-plot), basing on the Bray-Curtis similarity. Fourth root transformation (to downplay the effects of very abundant species) was applied prior to analysis.

To describe changes in diversity, we use a sample-size independent version of the Simpson index: SI $=\Sigma\left(\left(n^{2}-\right.\right.$ $n)) /\left(N^{2}-N\right)$ ), where $n$ is the number of individuals of a species (Attrill et al. 2001). The index determines the probability (values between 0 and 1) that any two individuals chosen at random belong to the same species. High values indicate dominance by one or very few taxa. Its complement (1-Simpson index) may be taken as an equitability index.

\section{Results}

Mussel bed area

Mussels formed dense beds along the low water line of the Königshafen. Area of site 1 was estimated to about 14 ha in
1992 (Nehls and Ketzenberg 2002). Site 1 reached a maximum area of 16 ha in 2000, when $48 \%$ of the mussel bed area was covered by mussels. Mussel patches were clearly distinct from the surrounding area and often elevated by $30-50 \mathrm{~cm}$. Mussel bed area decreased during the study period. In 1998 about 13.5 ha were present, but mussel bed area reached the lowest level of 6.2 ha in 2005 . Site 2 was destroyed by storms in 1998. Since then, no strong spatfall occurred that could have re-established losses in mussel bed area. This is the reason why data from 1999 onwards were only available from site 1.

Blue mussel biomass and densities

During the time of the first study in 1984 , blue mussel biomass reached $1,208 \pm 207 \mathrm{~g}$ AFDW $/ \mathrm{m}^{2}$. Highest values were found 8 years later in 1992, with 1,838 g AFDW/ $\mathrm{m}^{2}$. In later years, biomass dropped to a third of that found in the beginning of the 1990s (Fig. 2a). Lowest biomass values were obtained in 2000 with $259 \pm 170 \mathrm{~g} \mathrm{AFDW} / \mathrm{m}^{2}$. Mean biomass of both sites decreased significantly in the study period $\left(r_{\mathrm{s}}=-0.8, P<0.001\right)$

Mean mussel densities did not decrease significantly (Table 2). Blue mussel densities were highest in 1990 and in 1997/1998 (Fig. 2b), following a strong spatfall in 1996. No comparable spatfall occurred until 2005.
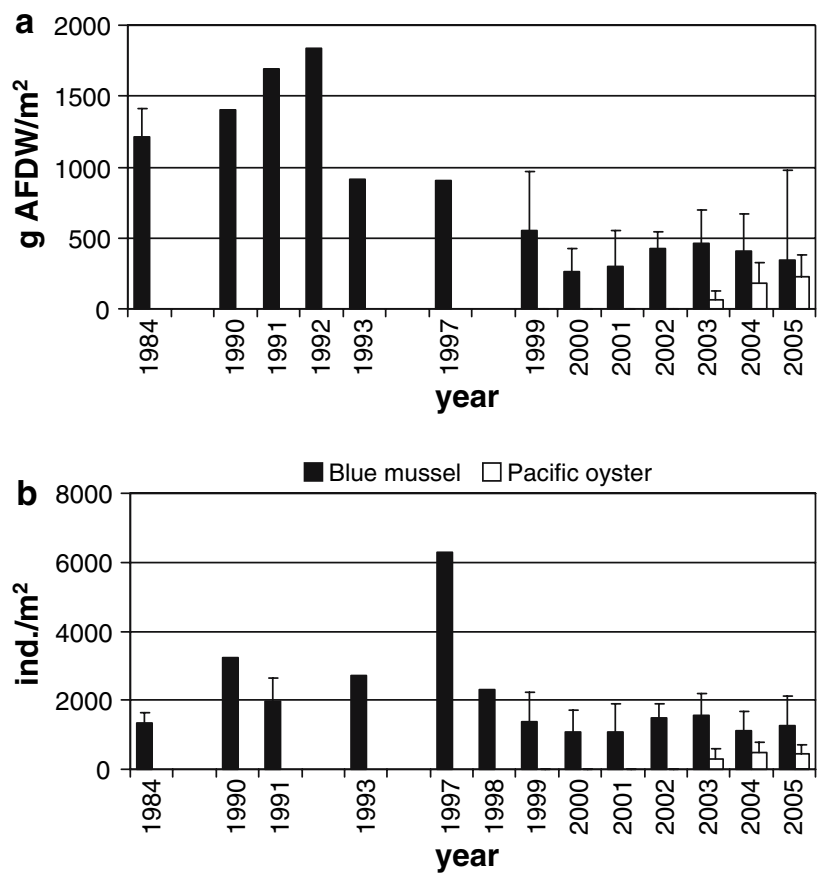

Fig. 2 Mean biomass (+SD) (a) and mean densities (+SD) (b) of blue mussels (Mytilus edulis) and Pacific oysters (Crassostrea gigas) on two mussel beds (sites 1 and 2) in Königshafen from 1984 to 2005. SD not available for all years 


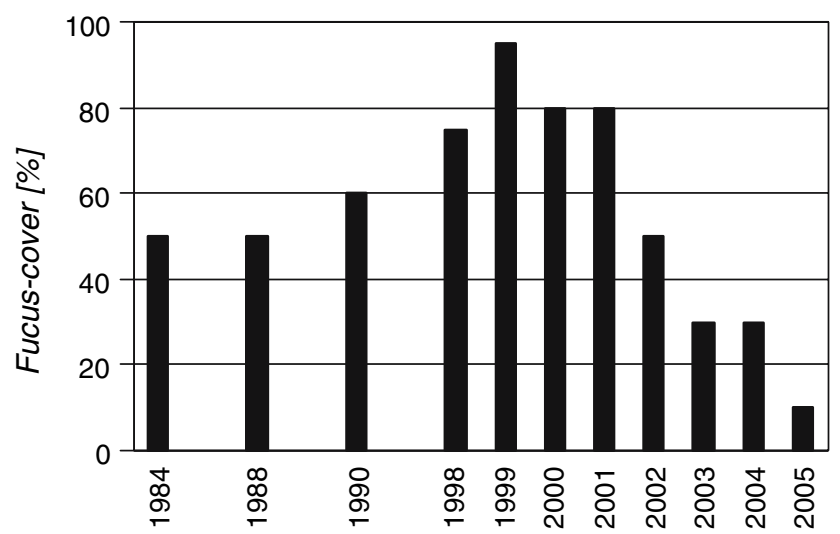

Fig. 3 Changes of Fucus-cover (\% of the mussel bed area)

\section{Fucus-cover}

Considerable parts of the mussel beds were covered by a dense layer of Fucus. About half of the mussel bed was covered in the 1980s, and the cover increased in the late 1990s. In 1999 cover was estimated at 95\%. Dry mass of the algae was about $730 \mathrm{~g} / \mathrm{m}^{2}$. Since then Fucus has decreased with only $10 \%$ cover remaining in 2005 (Fig. 3).

Species richness, diversity and patterns of single associated taxa

A total number of 65 taxa were found at least once during the mussel bed surveys (Table 2). The total number of taxa was lower in the first two years (1984 and 1990), with 23 and 25 respectively, whereas 45 taxa were recorded in 2003. In addition to the blue mussels themselves, 12 taxa (Capitella capitata, Heteromastus filiformis, Nereididae indet., Malacoceros sp., Carcinus maenas, Jaera albifrons, Actinaria indet., Littorina littorea, Nemertini indet., Lepidochitona cinereus, Balanus sp. and Cirratulidae indet.) occurred in all years. Records of 13 taxa in single years (with low mean densities) can be considered as rare.

Twenty-nine taxa which were not recorded in the first three surveys appeared between 1999 and 2005. Thirteen of these were found in 1 year only and at low densities. Another 11 of these 29 taxa occurred in 2 or 3 years in low densities and are regarded as rare as well. C. gigas was abundant in all surveys since 2002. Five taxa, Harmothoe imbricata, Polynoidae indet., Spio filicornis, Gammarus locusta and Gammarus oceanicus have occurred since 1999 in at least 4 years, with variable abundances.

Within the study period, no characteristic mussel bed species vanished. Densities of Chaetogammarus marinus, known to be closely associated with fucoid algae on which it is feeding, and G. locusta declined significantly $\left(r_{\mathrm{s}}=-1\right.$, $P=0$ and $r_{\mathrm{s}}=-0.88, P=0.01$; Table 2). Three polychaete species (Kefersteinia cirrata, Eumida sanguinea and Arenicola marina) which were found in low densities in 1984, 1990 and 1993, have not been recorded since 1999 and are regarded not to be typical for mussel beds.

Examining the number of all taxa determined to species level (Table 2), species richness was lowest in 1984 with 26 species found between September and November. Yet, in total, Asmus (1987) found 38 species during the whole year of his investigation (December 1983-November 1984). Species richness was also low (33 species) in 1990 (10 samples only), but highest (51 species) in 2003 (25 samples). Although richness estimates will be influenced by the variable numbers of samples taken in the different studies, the doubling of species from autumn 1983 (90 samples of $100 \mathrm{~cm}^{2}$ ) to 2003 (25 samples of $78.5 \mathrm{~cm}^{2}$ ) may indicate an increase.

The Simpson-index (M. edulis and C. gigas were not included) increased from 0.17 in 1984 to 0.76 in 2005. The values fluctuated slightly between 1999 and 2005, but they were always above 0.5 , and clearly higher than in 1984 , 1990 and 1993. This reflects an increasing dominance by a few species, and equitability declined respectively.

Biomass and densities of associated fauna

Overall, mean density of associated macrozoobenthos showed a significant positive trend over time $\left(r_{\mathrm{s}}=0.87\right.$, $P<0.001)$. Mean densities were comparatively low in 1984 and high since 2002, apart from 2004 (Fig. 4). This density increase came along with a biomass increase $\left(r_{\mathrm{s}}=0.78, P<0.05\right)$. Densities of the associated community did not correlate with mussel densities $\left(r_{\mathrm{s}}=0.03\right.$, $P=0.47)$.

Abundances of the associated community increased due to epibenthic species $\left(r_{\mathrm{s}}=0.87, P<0.001\right.$, Fig. 4b). Densities of endobenthic species did not show a significant trend, but were highest in 2003 with high abundances of Polychaeta, mainly of Cirratulidae indet., Nereididae indet. and (most importantly) Polydora sp. (see Table 2 for Spearman rank correlation). Barnacles were largely responsible for the overall increase in abundance by epibenthic species, and showed a significant positive trend $\left(r_{\mathrm{s}}=0.92, P<0.001\right)$. Densities of barnacles were highest in 2002 with 22,768 ind. $/ \mathrm{m}^{2}$ and they formed by far the highest proportion of all individuals.

Regarding those surveys which provided abundance data for different species of barnacles, the temporal patterns of densities differed among species. Balanus crenatus and Semibalanus balanoides were found in all years. 


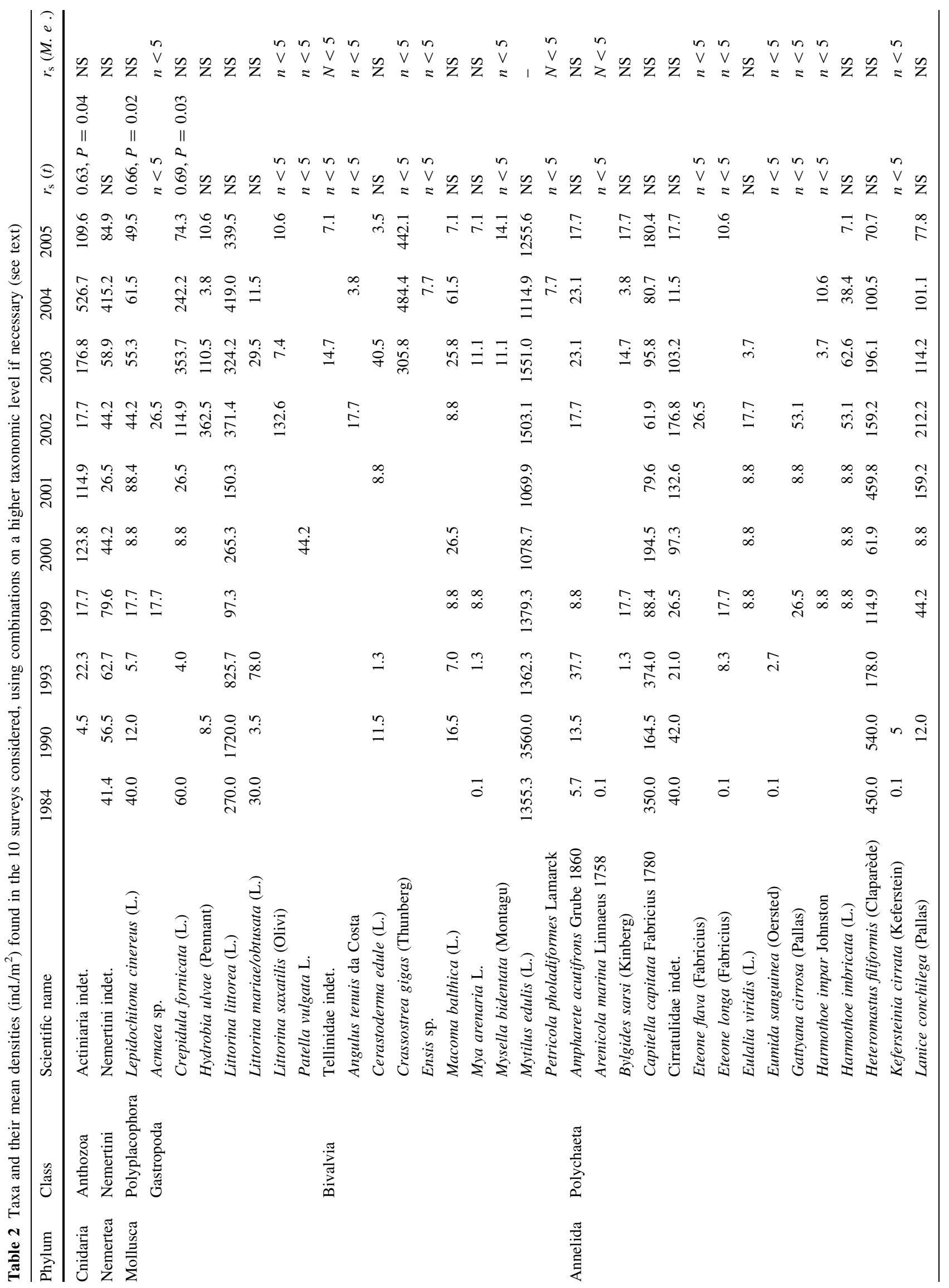




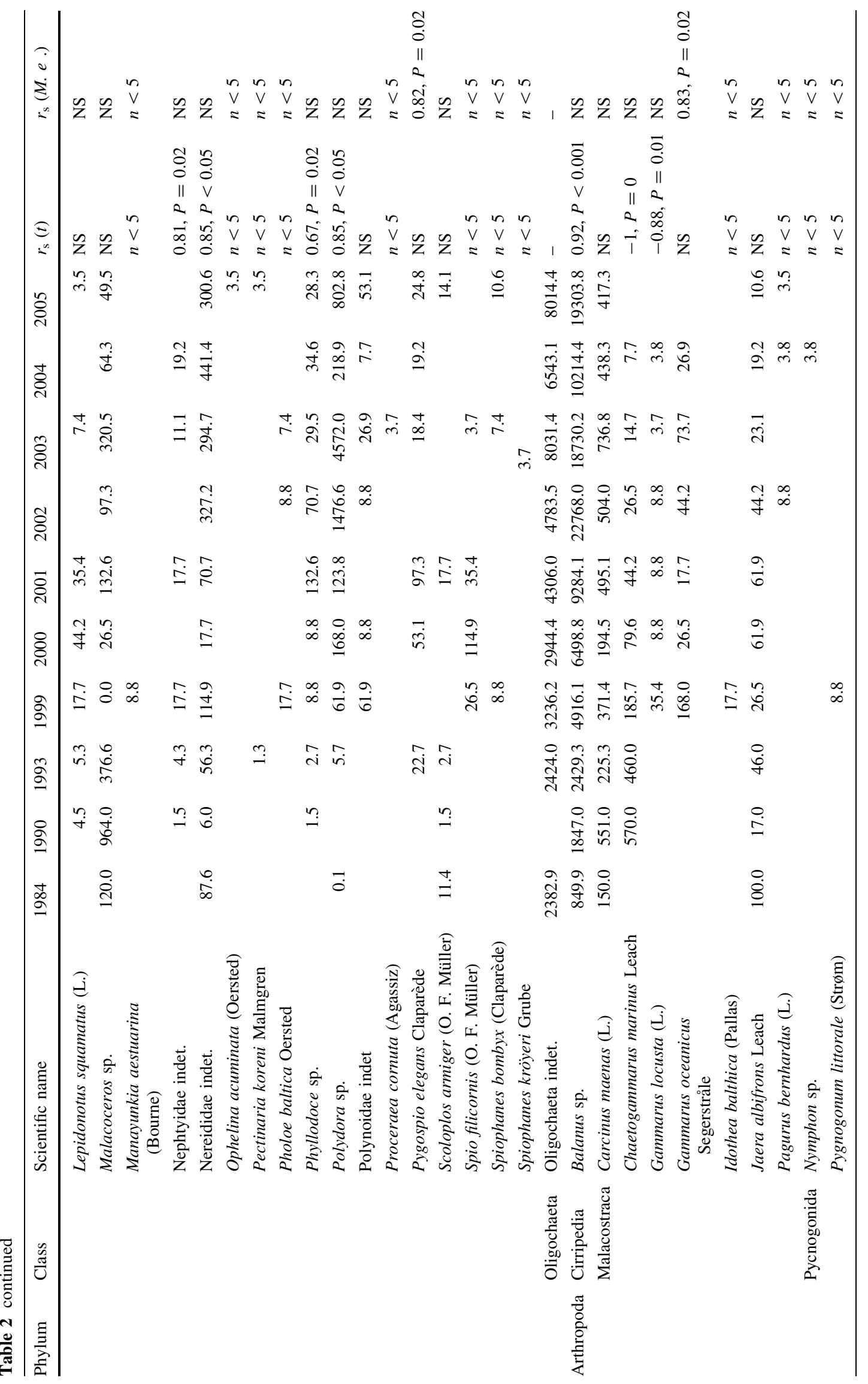




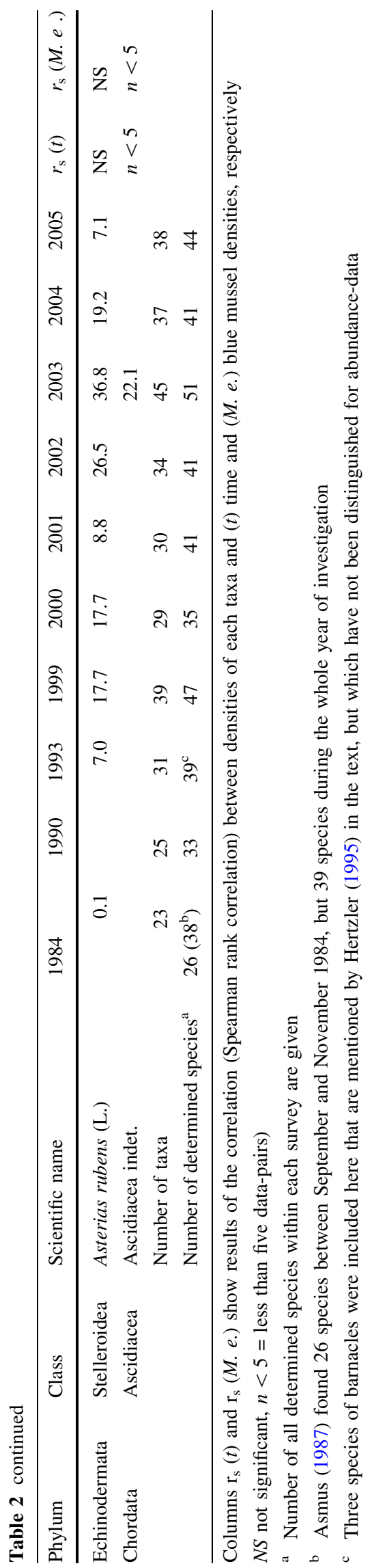

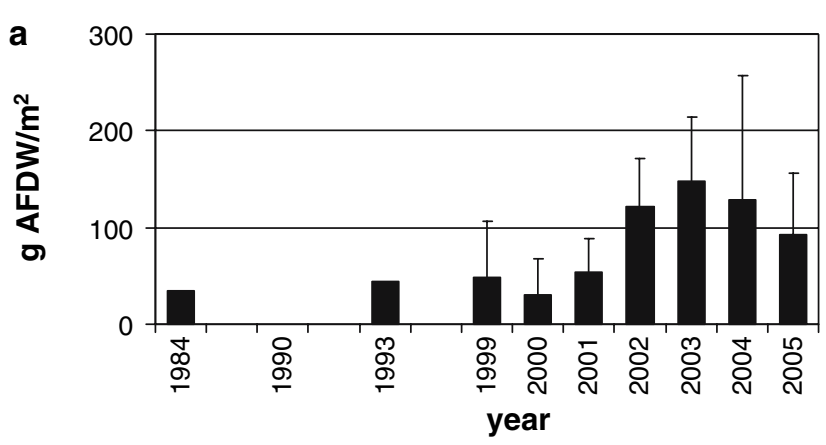

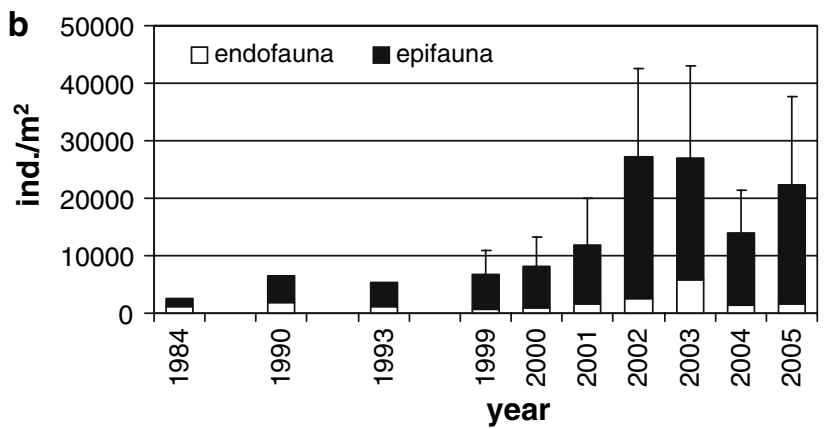

Fig. 4 Mean biomass (+SD) (a) and mean densities (divided in endofauna and epifauna, + SD is given for total mean densities) (b) of the associated macrozoobenthos on two mussel beds (sites 1 and 2) in the outer Königshafen from 1984 to 2005. Mytilus edulis, Crassostrea gigas and Oligochaeta indet. are not included. SD not always available

B. crenatus was most abundant in $2002(12,387 \pm$ 12,463 ind. $\left./ \mathrm{m}^{2}\right)$, but densities decreased afterwards. $S$. balanoides occurred with maximum densities in 2003 $\left(8,282 \pm 8,805 \mathrm{ind} . / \mathrm{m}^{2}\right)$, but they were lower in 2004 $\left(1,096 \pm 1,040 \mathrm{ind} . / \mathrm{m}^{2}\right)$ and $2005(1,316 \pm 1,541 \mathrm{ind} . /$ $\mathrm{m}^{2}$ ). Balanus improvisus always occurred in low densities. This barnacle was found for the first time in 1999 with $106 \pm 228$ ind. $/ \mathrm{m}^{2}$ and in 2003 with $335 \pm 768$ ind. $/ \mathrm{m}^{2}$. Densities were highest in $2005\left(742 \pm 2,995\right.$ ind. $\left./ \mathrm{m}^{2}\right)$. Elminius modestus reached high densities, especially in 2005 with $11,565( \pm 10,986)$ ind./ $/ \mathrm{m}^{2}$. This species occurred in 2000 for the first time in high numbers $\left(114 \pm 306\right.$ ind. $\left./ \mathrm{m}^{2}\right)$.

Apart from barnacles, few taxa showed increasing abundances. Although Oligochaeta were not included in the analysis, it is worth to mention that their abundances increased significantly $\left(r_{\mathrm{s}}=0.932, P<0.001\right)$ from 1984 $\left(2,383\right.$ ind. $\left./ \mathrm{m}^{2}\right) 2005$, with more than 8,000 ind. $/ \mathrm{m}^{2}$ and slightly lower densities in $2003\left(6,543\right.$ ind. $\left./ \mathrm{m}^{2}\right)$.

High biomass in 2002 and in the following years was mainly due to the species $B$. crenatus (between $18.4 \pm$ $15.6 \mathrm{~g} / \mathrm{m}^{2}$ and $43.6 \pm 32.1 \mathrm{~g} / \mathrm{m}^{2}$ ), S. balanoides (between $8.2 \pm 7.9 \mathrm{~g} / \mathrm{m}^{2}$ and $31.8 \pm 21.9 \mathrm{~g} / \mathrm{m}^{2}$ ), L. littorea (between $17.2 \pm 19.6 \mathrm{~g} / \mathrm{m}^{2}$ and $31.7 \pm 28 \mathrm{~g} / \mathrm{m}^{2}$ ) and C. maenas (between $5.4 \mathrm{~g} / \mathrm{m}^{2} \pm 5.6$ and $33.8 \pm 121.2 \mathrm{~g} / \mathrm{m}^{2}$ ). 
Development of alien species

We found several species likely to have been introduced (Tharyx killariensis, Aphelochaeta marioni, E. modestus, B. improvisus, C. fornicata, C. gigas, Ensis americanus, Petricola pholadiformes and Mya arenaria) associated with mussel beds in Königshafen. With the exception of the Pacific oyster and the barnacle B. improvisus, all introduced species were already present on the mussel beds in the first investigations performed in the 1980s and 1990s. The polychaete $T$. killariensis (first record 1972 in the Wadden Sea, Nehring and Leuchs 1999) and A. marioni (first record in the Wadden Sea 1967, Nehring and Leuchs 1999) were pooled with Chaetozone $c f$. setosa for the analysis as Cirratulidae indet. Densities did not change significantly (Table 2).

The occurrence and development of the barnacles E. modestus (introduced in the Wadden Sea 1943, Nehring and Leuchs 1999) and B. improvisus (introduced in 1858 in the Wadden Sea, Nehring and Leuchs 1999) is described above.

The American slipper limpet $C$. fornicata (1934 first record in the Lister Deep, Nehring and Leuchs 1999) prefers shallow subtidal areas. Therefore, density estimates of C. fornicata could be strongly influenced by the sampling procedure across the mussel beds. Our database shows increasing densities until 2003 (354 ind. $/ \mathrm{m}^{2}$ ) while the densities in the following years decreased again.

The American razor clam E. americanus (first record in 1978, Nehring and Leuchs 1999), and the bivalve P. pholadiformes (first record in 1896, Nehring and Leuchs 1999) were found in single years and with low densities.

The clam M. arenaria has occurred since at least 1860 in the German Wadden Sea (Nehring and Leuchs 1999), and was found at low densities in the mussel bed (our database).

Although the first feral Pacific oyster C. gigas was sighted at site 2 earlier in 1991 (Reise 1998), oysters did not occur in the samples before 2003. Mean oyster densities in 2003 to 2005 were about 400 ind. $/ \mathrm{m}^{2}$.

By 2005, about 54\% of all macrofaunal individuals (including blue mussels, except Oligochaeta indet.) on the mussel beds were represented by introduced species (including $C$. gigas). The numerically most important species were E. modestus, followed by B. improvisus and C. gigas. In 1984, alien species represented only $3 \%$ of all individuals.

Community structure and changes of functional groups

Multi-variate analyses indicate a major shift in community composition between the early and late 1990s (Fig. 5).

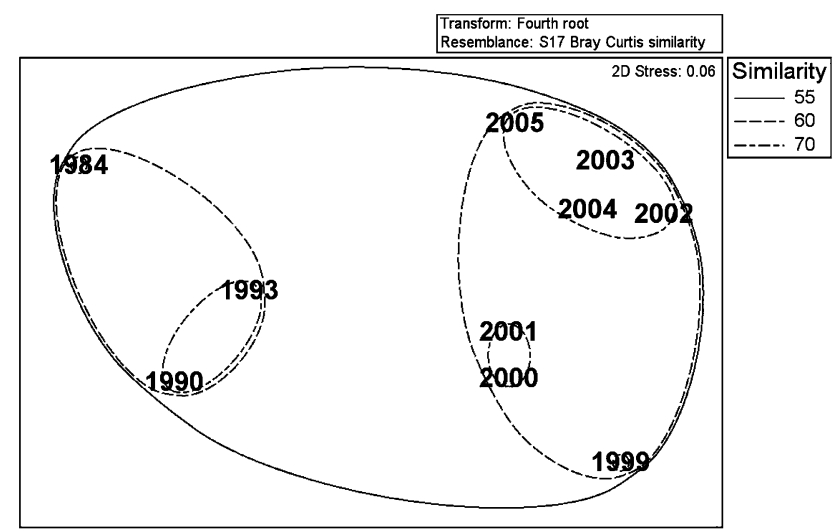

Fig. 5 Non-parametric multi-dimensional scaling plot (fourth root transformed, Bray-Curtis-similarity) for the macrozoobenthos community (between 1984 and 2005) on mussel beds in the outer Königshafen (Sylt, Germany). Additional similarity over all years with 55, 60 and 70\% are given (indicated with the closed and dashed lines) arbitrarily chosen from a cluster analysis (not shown)

Community compositions in 1990 and 1993 were similar to 1984, and in 1999 to 2001 also more similar to each other than in the surveys since 2002 .

Between 1984 and 1990/1993, changes reflect fluctuation in species composition and an increase of epibenthic species abundances. Later, community structure shifted mainly because of increasing abundances, notably by barnacles. Barnacles were treated in the analysis as one taxonomic group (see Methods). However, a shift from native to introduced barnacle species was apparent (see above).

Because of the strong increase in densities of barnacles, the absolute abundance of suspension feeders increased as well (Fig. 6) while the other functional groups showed less temporal fluctuation. Despite a marked qualitative change in dominant species, the community remained primarily a filter feeder assemblage.

\section{Discussion}

The results of the study revealed a shift from high to low biomass of mussel beds and from low to high abundances of the associated community which also changed in composition. However, there are also peaks of mussel density and of fucoid cover at an intermediate phase of the two decades of observation.

Mussel beds may form very stable and long-lived structures in the Wadden Sea, if losses from factors like hydrodynamic forces, storm events or predation are balanced by recruitment (Nehls and Thiel 1993, Dankers et al. 1999; Nehls and Ketzenberg 2002). Over recent years, the mussel bed area has been declining in many parts of the Wadden Sea as a result of recruitment failures (de Vlas 


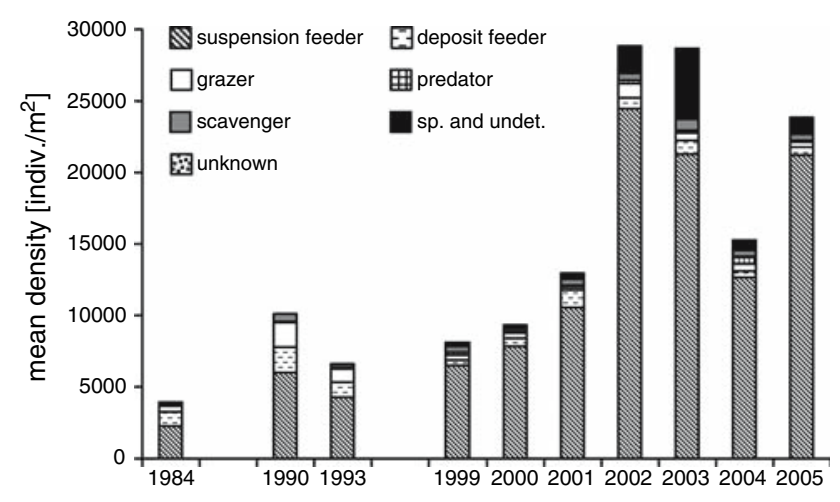

Fig. 6 Mean densities of functional groups between 1984 and 2005 (Mytilus edulis and Crassostrea gigas are included, Oligochaeta indet. were not considered)

et al. 2005, Nehls and Büttger 2007), thus the development in our study area is not a local phenomenon. The last massive recruitment in the northern Wadden Sea occurred in 1996 following a severe winter. Therefore, recruitment failure might be related to mild winters, whereas increasing summer temperatures facilitate oyster proliferation in the Wadden Sea (see details in Diederich et al. 2005; Nehls et al. 2006; Nehls and Büttger 2007).

We suggest that several processes have interacted and that invading species are not the only driving force that take advantage of changing mussel beds. Four changes in the mussel bed structure have to be considered: (1) a decrease in mussel biomass, (2) ageing of mussel beds, (3) decrease of Fucus cover since 2001, (4) increasing abundances of non-native species.

\section{A decrease in mussel biomass}

Although mussel densities did not decrease significantly, mussel biomass did, indicating a decline in large-sized mussels which in general dominate the biomass (Nehls and Ketzenberg 2002).

Reduced mussel biomass within the patches may well play a role in changing communities. Densely packed mussel patches which store high mussel biomass may enhance the accretion of the mussel beds by accumulating faeces and pseudofaeces and layers of dead shells, which might enhance the numbers of associated endofauna (Commito and Boncavage 1989, Ragnarsson and Raffaelli 1999). In contrast, experiments of Beadman et al. (2004) revealed an inverse relation between mussel cover on the one hand and species richness and abundance of associated infauna on the other hand. In our study, densities of endofauna (excluding Oligochaeta) increased since 2000 until 2003, whereas total density and biomass of blue mussels was lowest in this period. Dense mussel patches in the study area with high biodeposition have been found to harbour lower densities of Polychaeta (Dittmann 1990). In our study, densities of some polychaetes increased as mussel biomass decreased (Table 2) but no general trend appeared.

After 2003, mussels were partly replaced by Pacific oysters, which fulfil a similar ecological function from an infaunal point of view (as they also accumulate faeces and pseudofaeces). With the co-occurrence of blue mussels and oysters, total bivalve density and biomass increased since 2003 (Table 2).

We did not find any correlation between mussel density and the total densities of the associated epi- or endofauna. Increasing abundances of the associated community in our study were largely dominated by epibenthic species, especially barnacles. Mussels actively change their positions from bottom to top layers (Okun 1999). When they are on the bottom of the stack, survival of epifauna may be reduced. More detailed research on the interactions between mussel densities and associated epifauna is recommended.

Ageing of mussel beds

A second possible reason for the observed changes could be the ageing of mussel beds. The last strong spatfall of blue mussels in the study area occurred after the cold winter of 1995/1996 (Hertlein 1997) and led to mussel beds with several thousands of young mussels per square meter. Subsequently, although densities declined, biomass remained constant over several years as decreasing mussel numbers were counteracted by the larger sizes of the mussels (Guinez 2005). Older mussel beds become more heterogeneous in physical structure (Tsuchiya and $\mathrm{Ni}$ shihira 1986; Günther 1996; O'Connor and Crowe 2007), because of an increasing number of dead shells, and higher densities of associated species than young mussel beds (such as barnacles, see Buschbaum 2001). In addition young mussels are able to clean their shell with their foot, and shells of young M. edulis have a slick surface with a closed and uneroded periostracum (inhibiting epifaunal settlement) that is lost as older mussels abrade them (Theisen 1972; Fig. 7). Older blue mussels thus offer much better opportunities for settling epifauna. Increasing oyster densities since 2003 also facilitate settling of epifauna.

\section{Decrease of Fucus cover}

Reasons for the up- and downward trends in Fucus-cover on mussel beds in the outer Königshafen are unclear. Fucus cover positively enhances the occurrence of some 


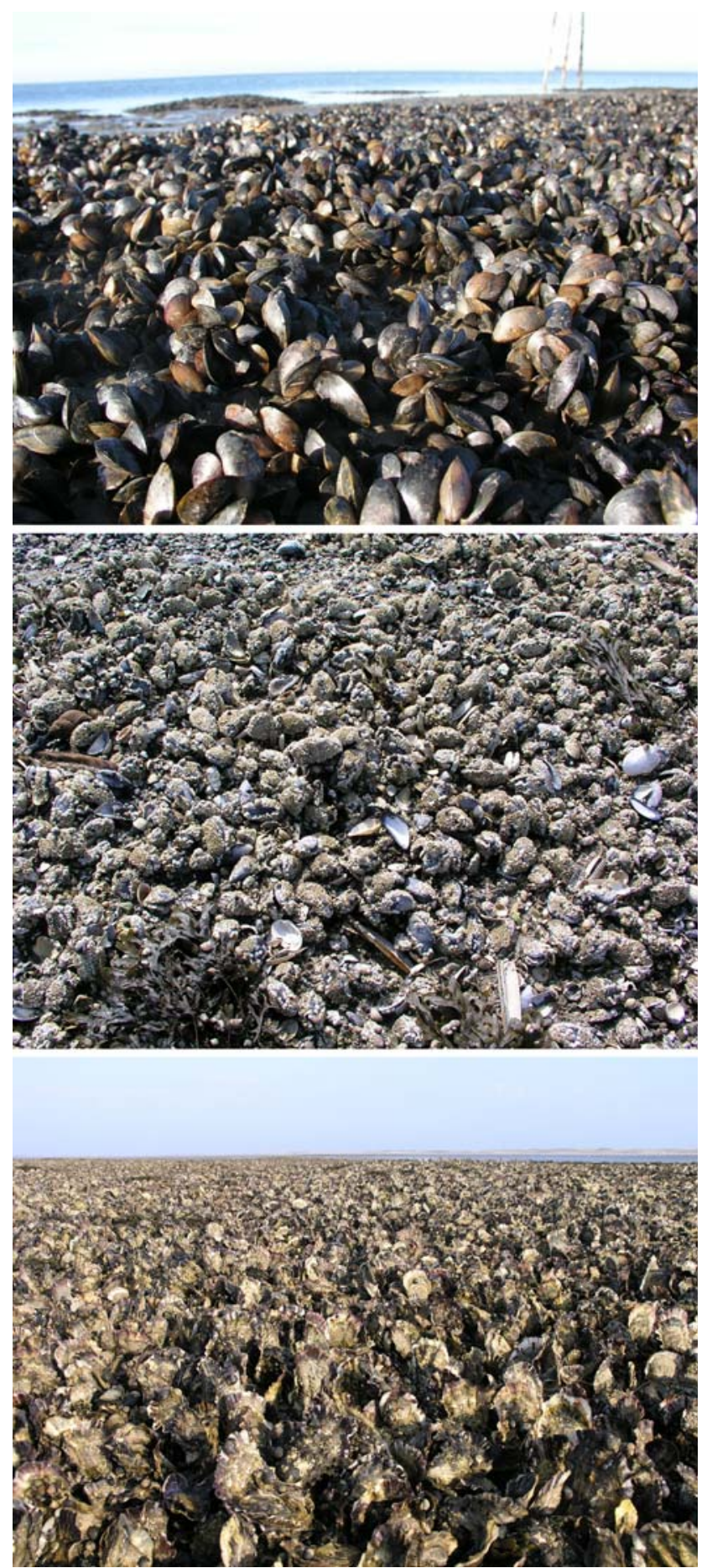

Fig. 7 A young mussel bed (top), an older mussel bed (middle) and an oyster dominated bed (bottom) to illustrate structural differences

epibenthic species, such as Littorina mariae, Jaera albifrons and Gammarus sp., while other species, especially barnacles and L. littorea are depressed beneath Fucus-cover (Albrecht and Reise 1994). As Fucus acts as sediment trap, the sediment of the mussel beds gets muddier. This often results in decreasing mussel densities and attached epifauna. Decrease in Fucus cover is thus likely to be an important factor for the increase of epibenthic species, especially barnacles. On the other hand, the decrease of species as J. albifrons and Chaetogammarus marinus is also considered to be a result from loss of this seaweed. These species are most closely linked to the Fucus 'canopy' on the mussel beds, which offers shelter against predators and against desiccation at low tide. J. albifrons and C. marinus rarely occur outside the algal cover. Densities of $C h$. marinus decreased significantly until 2004 (Table 2) and no individuals were found in 2005. To judge if these species have disappeared from this mussel bed or not data of the following years associated with information about the occurrence of the fucoid algae are needed.

Increasing abundances of non-native species

In two decades covered by the data set, diversity decreased (Simpson index), indicating the dominance of a few species. Together with Pacific oysters, American slipper limpets and some others, alien species have achieved numerical dominance on the mussel beds. Among alien species, only the Pacific oyster is a recent inhabitant of the mussel beds. All other alien species were already present during our first study in Königshafen or were detected decades before in the Wadden Sea (Nehring and Leuchs 1999). Thus, introductions did not contribute to an increase in species richness within the period considered here.

However, the introduced Pacific oyster plays a special role as it increasingly takes in the place of the blue mussel as a habitat builder. Individuals of the Pacific oyster were first recorded in 1991 on intertidal mussel beds in the List Tidal Basin (Reise 1998). Low densities (3.9 oysters $/ \mathrm{m}^{2}$ ) were found from 1999 until 2002 (Diederich et al. 2005), followed by several years of good spatfalls leading to rapidly increasing oyster densities and biomass (Nehls and Büttger 2007; $314 \pm 200$ ind./ $\mathrm{m}^{2}$ in 2003, Fig. 2). After 2003, the mussel bed turned into an oyster reef with tightly packed oysters standing vertically (Fig. 7). Oyster densities and biomass reported in Fig. 2 are likely to be underestimated, as large oysters and clumps were difficult to sample using a corer. Separate oysters sampling yielded higher densities (about 1,800 indiv. $/ \mathrm{m}^{2}$ in 2007; Nehls and Büttger, unpublished, compare Nehls and Büttger 2007). Like mussel beds, oysters offer a heterogeneous physical structure which serves as a habitat for many associated species, and also act as ecosystem engineers (Jones et al. 1994; Commito and Dankers 2001; Crooks 2002; Palomo et al. 2007). Although competition for limited space and probably also for food is anticipated to be important at a small scale at least, there is still no evidence that oysters have displaced mussels (Nehls et al. 2006; Nehls and Büttger 
2007). Whether or not the spread of the Pacific oysters has promoted the increase of other alien species such as Balanus improvisus or Elminius modestus cannot be concluded from our data. Like in native barnacles, their spread is considered to be facilitated by decreasing Fucus cover. Additionally, the barnacle E. modestus, in particular, is expected to take advantage of mild winters (Harms 1998). This introduced species competes for space with the native S. balanoides (Nehring and Leuchs 1999; Franke and Gutow 2004). This shift in dominance seems to be induced by climatic factors and supported by structural factors, and oysters are assumed to offer more surface for settlement when they grow tightly packed in vertical position (compare Markert 2006). Increasing abundances of the nonnative $C$. fornicata were facilitated by mild winters (Nehls et al. 2006). Since oysters became more abundant, densities of $C$. fornicata decreased probably due to the fact that the American slipper limpet was not observed in higher densities on densely packed oysters. Additionally this species preferentially occurs below low water line (Thieltges et al. 2003) rather than on elevated oyster patches. All other nonnative species did not show clear trends of their abundances.

Alien species thus play an important role in species turnover of the mussel bed community. Decreasing mussel biomass followed by increasing oyster densities was apparently facilitated by climatic factors (Diederich et al. 2005) and supported increasing densities of the associated community and structural changes in the study period.

\section{Conclusions and outlook}

All four factors discussed earlier are assumed to contribute to changing community structure of intertidal mussel beds. Two of them are considered as common processes in Wadden Sea mussel beds; ageing of mussels and selfthinning of mussel beds (Guinez 2005) probably lead to a natural succession of the associated community. In the following years after the spatfall, as shown in this study, the stability of the mussel beds was lost; they deteriorated and were partly taken over by invading oysters. With the background of a very fast increasing population in the entire Wadden Sea, oysters are set to take over the role of mussels as ecosystem engineers. The effects of $C$. gigas on the benthic communities in the Wadden Sea will be composed of direct structural attributes and species interactions, and further modulated by climate change and changing of Fucus cover.

Acknowledgments We thank Karsten Reise and two anonymous reviewers for valuable comments and criticism. The work of $\mathrm{G}$. Nehls and H. Büttger is supported by the Regional Office of the
Wadden Sea National Park of Schleswig-Holstein. Many people helped in fieldwork during the various studies. Günter Sach and his team at Rendsburger Werkstätten analysed and processed all samples since 1999, and his work and expertise is gratefully acknowledged. The project has been carried out in the framework of the MarBEF Network of Excellence 'Marine Biodiversity and Ecosystem Functioning' which is funded by the Sustainable Development, Global Change and Ecosystems Programme of the European Community's Sixth Framework Programme (contract no. GOCE-CT-2003-505446). This publication is contribution number MPS-07090 of MarBEF.

\section{References}

Albrecht A (1991) Einfluß der Braunalge Fucus vesiculosus auf die Lebensgemeinschaft von Miesmuschelbänken im Wattenmeer. Diplomarbeit, University of Göttingen, Germany

Albrecht A, Reise K (1994) Effects of Fucus vesiculosus covering intertidal mussel beds in the Wadden Sea. Helgol Meeresunters 48:243-256

Asmus H (1987) Secondary production of an intertidal mussel bed community related to its storage and turnover compartments. Mar Ecol Prog Ser 39:251-266

Attrill MJ, Stafford R, Rowden AA (2001) Latitudinal diversity patterns in estuarine tidal flats: indications of global cline. Ecography 24:318-324

Austen G (1994a) Hydrodynamics and particulate matter budget of Königshafen, southeastern North Sea. Helgol Meeresunters 48:183-200

Austen I (1994b) The surficial sediments of Königshafen; variations over the past 50 years. Helgol Meeresunters 48:163-171

Beadman HA, Kaiser MJ, Galanidi M, Shucksmith R, Willows RI (2004) Changes in species richness with stocking density of marine bivalves. J Appl Ecol 41:464-475

Beukema JJ (1991) Changes in the composition of bottom fauna of a tidal-flat area during a period of eutrophication. Mar Biol 111:293-301

Beukema JJ (1992) Expected changes in the Wadden Sea benthos in a warmer world: lessons from periods with mild winters. Neth $\mathbf{J}$ Sea Res 30:73-79

Buschbaum C (2001) Siedlungsmuster und Wechselbeziehungen von Seepocken (Cirrepedia) auf Muschelbänken (Mytilus edulis L.) im Wattenmeer. PhD Thesis, University of Hamburg, Germany

Buschbaum C, Saier B (2001) Growth of the mussel Mytilus edulis in the Wadden Sea affected by tidal emergence and barnacle epibionts. J Sea Res 45:27-36

Clarke KR, Warwick RM (2001) Change in marine communities: an approach to statistical analysis and interpretation, 2nd edn. Primer-E, Plymouth

Commito JA, Boncavage EM (1989) Suspension-feeders and coexisting infauna: an enhancement counterexample. J Exp Mar Ecol 125:33-42

Commito JA, Dankers NMJA (2001) Dynamics of spatial and temporal complexity in European and North American softbottom mussel beds. In: Reise K (ed) Ecological comparisons of sedimentary shores. Ecol Stud 151:39-59

Crooks JA (2002) Characterizing ecosystem-level consequences of biological invasions: the role of ecosystem engineers. Oikos 98:153-166

Dankers N, Brinkman AG, Meijboom A, Zegers J (1999) Recovery of intertidal mussel beds in the Wadden Sea after long term destruction. J Shellfish Res 18:713

de Vlas J, Brinkman B, Buschbaum C, Dankers N, Herlyn M, Kristensen PS, Millat G, Nehls G, Ruth M, Steenbergen J, 
Wehrmann A (2005) Intertidal Blue Mussel beds. In: Essink K, Dettmann C, Farke H, Laursen K, Lüerßen G, Marencic H, Wiersinga W (eds) Wadden Sea Quality Status Report 2004. Common Wadden Sea Secretariat, Wilhelmshaven, pp 190-200

Diederich S (2005) Invasion of Pacific oysters (Crassostrea gigas) in the Wadden Sea: competitive advantage over native mussels. $\mathrm{PhD}$ Thesis, University of Kiel, Germany

Diederich S, Nehls G, van Beusekom JEE, Reise K (2005) Introduced Pacific oysters (Crassostrea gigas) in the northern Wadden Sea: invasion accelerated by warm summers? Helgol Mar Res 59:97106

Dittmann S (1990) Mussel beds - amensalism or amelioration for intertidal fauna? Helgol Meeresunters 44:335-352

Franke HD, Gutow L (2004) Long-term changes in the macrozoobenthos around the rocky island of Helgoland (German Bight, North Sea). Helgol Mar Res 58:303-310

Gätje C, Reise K (1998) Ökosystem Wattenmeer, Austausch-, Transport- und Stoffumwandlungsprozesse. Springer, Berlin

Guinez R (2005) A review on self-thinning in mussels. Revista de Biologia Marina y Oceanografia 40:1-6

Günther CP (1996) Development of small Mytilus beds and its effects on resident intertidal macrofauna. PSZNI Mar Ecol 17:117-130

Gutiérrez JL, Jones CG, Strayer DL, Iribane OO (2003) Mollusks as ecosystem engineers: the role of shell production in aquatic habitats. Oikos 101:79-90

Hagberg J, Tunberg BJ, Wieking G, Kröncke I, Belgrano A (2004) Effects of climate variability on benthic communities. In: Stenseth NC, Ottersen G (eds) Marine ecosystems and climate variation-The North Atlantic-a comparative perspective. Oxford University Press, New York, pp 115-121

Harms J (1998) The neozoan Elminius modestus Darwin (Crustacea, Cirripedia): possible explanations for its successful invasion in European waters. Helgol Meeresunters 52:337-345

Hertlein A (1997) Assoziierte Epifauna der Miesmuschelbänke (Mytilus edulis L.) im Sylter Wattenmeer. Diplomarbeit, University of Bonn

Hertzler I (1995) Nahrungsökologische Bedeutung von Miesmuschelbänken für Vögel (Laro-Limikolen) im Nordfriesischen Wattenmeer. Diplomarbeit, University of Göttingen, Germany

Jones CG, Lawton JH, Shachak M (1994) Organisms as ecosystem engineers. Oikos 69:373-386

Kröncke I, Zeiss B, Rensing C (2001) Long-term variability in macrofauna species composition off the island of Norderney (East Frisia, Germany) in relation to changes in climatic and environmental conditions. Senckenb Marit 31:65-82

Markert A (2006) Untersuchung der Lebensgemeinschaft eines durch die Pazifische Auster (Crassostrea gigas) neu entstandenen Austernriffs im Ostfriesischen Wattenmeer. Diplomarbeit, University of Berlin, Germany

Nehls G, Büttger H (2007) Spread of the Pacific oyster Crassostrea gigas in the Wadden Sea-causes and consequences of a successful invasion. HARBASINS Report, CWSS, Wilhelmshaven, pp 54

Nehls G, Ketzenberg C (2002) Do common Eiders Somateria mollissima exhaust their food resources? A study on natural mussel Mytilus edulis beds in the Wadden Sea. Dan Rev Game Biol 16:47-61

Nehls G, Thiel M (1993) Large-scale distribution patterns of the mussel Mytilus edulis in the Wadden Sea of SchleswigHolstein: do storms structure the ecosystem? Neth J Sea Res 31:181-187

Nehls G, Diederich S, Thieltges DW, Strasser M (2006) Wadden Sea musselbeds invaded by oysters and slipper limpets: competition or climate control? Helgol. Mar Res 60:135-143
Nehring S, Leuchs H (1999) Neozoa (Makrozoobenthos) an der deutschen Nordseeküste - Eine Übersicht. Bundesamt für Gewässerkunde, Koblenz. Bericht BfG-1200, pp 131

O'Connor NE, Crowe TP (2007) Biodiversity among mussels: separating the influence of size of mussels from the ages of patches. J Mar Biol Assoc UK 87:551-557

Okun N (1999) Einfluß der Sedimentation auf die Miesmuschel (Mytilus edulis L.). Diplomarbeit, University of Hamburg, Germany

Palomo MG, People J, Chapman MG, Underwood AJ (2007) Separating the effects of physical and biological aspects of mussel beds on their associated assemblages. Mar Ecol Prog Ser 344:131-142

Parusel E (1990) Die Bedeutung der Braunalge Fucus vesiculosus forma mytili (Nienburg) Nienhuis für den Nährstoffumsatz einer „Fucus-Mytilus-Bank" unter besonderer Berücksichtigung der Nährstoffversorgung der Algen. Diplomarbeit, University of Bremen, Germany

Philippart CJM, Anadón R, Danovaro R, Dippner JW, Drinkwater KF, Hawkins SJ, O’Sullivan G, Oguz T, Reid PC (2007) Impacts of climate change on the European Marine and coastal environment. European Sciences Foundation, Position Paper 9, pp 84

Ragnarsson S, Raffaelli DG (1999) Effects of the mussel Mytilus edulis on the invertebrate fauna of sediments. J Exp Mar Biol Ecol 241:31-44

Reichert K, Buchholz F (2006) Changes in the macrozoobenthos of the intertidal zone at Helgoland (German Bight, North Sea): a survey of 1984 repeated in 2002. Helgol Mar Res 60:213-223

Reise K (1982) Longterm changes in the macrobenthic invertebrate fauna of the Wadden Sea: are polychaetes about to take over? Neth J Sea Res 16:29-36

Reise K (1985) Tidal flat ecology. Springer, Berlin

Reise K (1998) Pacific oysters invade mussel beds in the European Wadden Sea. Senckenb Marit 28:167-175

Reise K, Herre E, Sturm M (1994) Biomass and abundance of macrofauna in intertidal sediments of Königshafen in the northern Wadden Sea. Hegol Meeresunters 48:201-215

Reise K, Dankers N, Essink K (2005) Introduced species. In: Essink K, Dettmann C, Farke H, Laursen K, Lüerßen G, Marencic H, Wiersinga W (eds) Wadden Sea Quality Status Report 2004. Common Wadden Sea Secretariat, Wilhelmshaven, pp 155-161

Schürmann A (1998) Bestand und Biomasse der Miesmuschel (Mytilus edulis L.) im Königshafen unter Berücksichtigung verschiedener Muschelbankstrukturen. Diplomarbeit, Technische Hochschule Aachen, Germany

Smaal A, van Stralen M, Craeymeersch J (2005) Does the introduction of the pacific oyster Crassostrea gigas lead to species shifts in the Wadden Sea? In: Dame DF, Olenin S (eds) The comparative roles of suspension-feeders in ecosystems. Proceedings of the NATO Advanced Research Workshop, Nida, Lithuania, 4-9 October 2003, 14p

Stachowicz JJ, Terwin JR, Whitlatch RB, Osman RW (2002) Linking climate change and biological invasions: ocean warming facilitates nonindigenous species invasions. PNAS 99:15497-15500

Strasser M, Reinwald T, Reise K (2001) Differential effects of the severe winter 1995/96 on the intertidal bivalves Mytilus edulis, Cerastoderma edule and Mya arenaria in the Northern Wadden Sea. Helgol Mar Res 55:190-197

Suchanek TH (1980) Diversity in natural and artificial mussel bed communities of Mytilus californianus. Am Zool 20:807

Theisen BF (1972) Shell cleaning and deposit feeding in Mytilus edulis L. (Bivalvia) Ophelia 10:49-55

Thiel M, Dernedde T (1994) Recruitment of shore crabs Carcinus maenas on tidal flats: mussel clumps as an important refuge for juveniles. Helgol Meeresunters 48:321-332 
Thieltges DW, Strasser M, Reise K (2003) The American slipper limpet Crepidula fornicata (L.) in the northern Wadden Sea 70 years after its introduction. Helgol Mar Res 57:27-33

Trilateral Monitoring and Assessment Group (1997) TMAP manual. The Trilateral Monitoring and Assessment program (TMAP). Common Wadden Sea Secretariat, Wilhelmshaven

Tsuchiya M, Nishihira M (1985) Islands of Mytilus as a habitat for small intertidal animals: effect of island size on community structure. Mar Ecol Prog Ser 25:71-81
Tsuchiya M, Nishihira M (1986) Islands of Mytilus edulis as a habitat for small intertidal animals: effect of Mytilus age structure on the species composition of the associated fauna and community organization. Mar Ecol Prog Ser 31:171-178

Valiela I (2005) Marine ecology processes. Springer, New York 